\title{
Availability of Dietary Zinc Sources and Effects on Performance of Pacific White Shrimp Litopenaeus vannamei(Boone)
}

\author{
Anant S. Bharadwaj ${ }^{\mathrm{a}}$, Susmita Patnaik ${ }^{\mathrm{b}}$, Craig L. Browdy ${ }^{\mathrm{a}}$, and Addison L. Lawrence ${ }^{\star b}$ \\ ${ }^{a}$ Novus International Inc., 20 Research Park Drive, St. Charles, MO 63304 USA \\ ${ }^{\mathrm{b}}$ Texas A\&M AgriLife Research Mariculture Laboratory, Texas A\&M University System, Port Aransas, TX 78373
}

\begin{abstract}
A B S T R A C T
A study was conducted to evaluate the response of Pacific white shrimp Litopenaeus vannamei to inorganic or chelated sources of dietary zinc. Two sets of diets, one supplemented with zinc from zinc sulfate $(55,80,116,168,243$ and $363 \mathrm{ppm}$ zinc) and the other with zinc from a chelated source (methionine hydroxy analog chelate; 39, 52, 65, 78 and $104 \mathrm{ppm}$ zinc) were fed to replicate groups of juvenile shrimp ( $N=8 ; 0.4 \mathrm{~g}$ initial weight) for $6 \mathrm{wk}$. All experimental diets contained $1.38 \%$ phytic acid reflecting levels in typical commercial feeds. Final weight, growth rate and biomass of shrimp fed zinc sulfate supplemented diets $(243$ and $363 \mathrm{ppm}$ total zinc) were significantly higher $(\mathrm{p}<0.05)$ than that in shrimp fed the base diet. In contrast, performance of shrimp fed the chelated source of zinc was significantly higher than shrimp in the control group at much lower levels of supplementation (65 and $78 \mathrm{ppm}$ total zinc). Results indicate that shrimp required 3-4 times more dietary zinc from zinc sulfate than zinc from a chelated source to promote comparable growth when fed diets containing phytic acid. The chelate tested proved to be a safe, effective and available source of zinc for the Pacific white shrimp.
\end{abstract}

Keywords: Pacific white shrimp; L. vannamei; chelated zinc source; phytic acid; bioavailability; cost effective feeds; growth

\section{Introduction}

Zinc is an essential trace element for both terrestrial and aquatic animals and plays vital roles in metabolism, structural integrity and regulatory function (Cousins, 1996; Davis and Gatlin, 1996; Watanabe et al., 1997; Underwood and Suttle, 1999; Lall, 2002; Shiau and Bai, 2009). It is estimated that proteins with zincbinding domains account for approximately $10 \%$ of the total human proteome and it is likely that this is the case across animal species (Andreini et al., 2006). Zinc is an important component of numerous enzymes and transcription factors and plays crucial roles in cellular growth, immune function, reproduction, neural function, connective tissue metabolism and antioxidant function (Starcher et al., 1980; Coleman, 1992; Shankar and Prasad, 1998; Underwood and Suttle, 1999; Blanchard et al., 2001; Ho et al., 2003; Cousins et al, 2003). Zinc is an essential trace element for shrimp and other crustaceans (Davis et al., 1992; Shiau and Jiang, 2006) and is known to play important roles in immune function, lipid metabolism, gene expression,

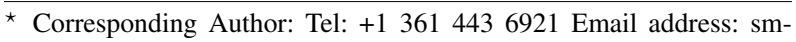
pall@yahoo.com reproduction and growth (Mendez et al., 2001; Shiau and Jiang, 2006; Li et al., 2010).

The availability of zinc from feed ingredients such as fish meal that have historically been the main protein source in feeds is typically low due to the presence of tricalcium phosphate which interferes with the absorption of zinc (Satoh et al., 1987; Watanabe et al., 1988). The decline in fish meal use due to rising costs and limited availability has necessitated the increased use of plant proteins (Tacon and Metian, 2008; Naylor et al, 2009). However, the use of high levels of plant protein sources in feeds may result in the reduced availability of zinc and other trace minerals, due to the presence of phytic acid. Phytic acid binds with divalent trace minerals and reduces their availability to animals resulting in loss to the environment as waste (Cheryan, 1980; Davis et al., 1993; Davis and Gatlin, 1996; Li and Robinson, 1997; Helland et al., 2006). The lower availability of zinc from feeds could impact the growth and health of both cultured and wild populations and is an area of serious concern (Ahsanullah et al., 1981; Munsiri et al., 1996; Wu and Chen, 2005; Cheung and Wong, 2006; Wu et al., 2008; Azevedo et al., 2009; $\mathrm{Wu}$ and Yang, 2011; Umamaheshwari et al., 2011). The alternative to meet the nutritional requirement for zinc in shrimp di- 
ets would be to significantly increase dietary zinc levels which would have the potential negative effect of increasing discharge of zinc into the environment.

Organic trace minerals are considered to be more available than inorganic trace minerals. There have been several studies in fish demonstrating higher availability of minerals from organic sources (Hardy and Shearer, 1985; Paripatananont and Lovell, 1995a; 1997; Apines et al., 2003; Apines-Amar et al., 2004b; Buentello et al., 2009; Shao et al., 2010). Typically organic trace minerals are more stable in the gastrointestinal tract and less susceptible to interactions and binding with antagonists as they are bound to organic ligands. Some commonly available organic trace minerals are in the form of metal proteinates, metal amino acid complexes and metal amino acid chelates. Studies have demonstrated improved bioavailability, growth and disease resistance in fish fed metal proteinates (zinc proteinate) and metal amino acid complexes (zinc methionine) compared to fish fed inorganic sources (Hardy and Shearer, 1985; Paripatananont and Lovell, 1995a;b; Buentello et al., 2009). The glycine chelates of trace minerals have also been shown to improve performance, tissue mineral retention, immune function and disease resistance in the rainbow trout despite the presence of dietary antagonist such as phytic acid and tricalcium phosphate (Satoh et al., 2001; Apines et al., 2003; Apines-Amar et al., 2004a;b) and in red sea bream (Sarker et al., 2005). More recently, divalent trace minerals chelated to HMTBa (2hydroxy-4-methylthiobutanoic acid; hydroxy analog of methionine; Mintrex ${ }^{\mathrm{TM}}$; Novus International Inc, St. Charles, USA) have become available for use in animal feeds. The stability of these molecules makes them less available to binding to phytic acid enabling them to reach receptors in the gut wall where they are absorbed into circulation (Yi et al., 2007; Richards et al., 2010).

In a recent study Pacific white shrimp $L$. vannamei fed a diet containing a zinc-methionine complex performed significantly better than shrimp fed either a zinc-deficient control diet or diets containing zinc sulfate or zinc complexed to lysine or glycine (Lin et al., 2013). These diets used in the study were purified diets based on casein and gelatin and the response of shrimp to such sources in practical diets that contain various mineral antagonists is not fully understood. There is limited information on the availability of organic or chelated trace minerals in shrimp fed either phytic acid-containing or phytic acid-free diets. The effect of phytic acid on mineral availability has however been well documented in fish (Spinelli et al., 1983; Richardson et al., 1985; Helland et al., 2006; Laining et al., 2010) but has been less studied in shrimp. Phytic acid did not adversely affect growth in Penaeus japonicus but depressed growth in L. vannamei (Civera and Guillaume, 1989). A dietary excess of zinc was required to overcome the effects of phytic acid and to restore levels of growth observed in L. vannamei fed diets without phytic acid (Davis et al., 1993). Increasing dietary zinc levels in response to decreased bioavailability results in higher losses of zinc into the environment from aquatic production systems.
Therefore the objective of this study was to evaluate the effects of inorganic and chelated dietary zinc sources on performance and tissue zinc retention in Pacific white shrimp L. vannamei fed diets containing phytic acid.

\section{Materials and Methods}

\subsection{Experimental diets}

A base diet composed mainly of wheat starch, casein, gelatin, squid meal and soy protein isolate was formulated to be deficient in zinc (24 ppm zinc) (Table 1). The diet, formulated to contain approximately $35 \%$ crude protein and $8 \%$ crude fat, met all nutritional requirements of the Pacific white shrimp (Table 2).

The vitamin premix used in the diet was devoid of zinc and other trace minerals; copper was added separately to the diet in the form of Mintrex ${ }^{\mathrm{TM}}$ copper, manganese as manganese sulfate, potassium as potassium chloride, calcium as calcium carbonate and magnesium as magnesium oxide respectively to meet requirements for this species. All diets were mixed and pelleted at the Texas A\&M AgriLife Research Mariculture Laboratory, Port Aransas, Texas. Pellets were manufactured using a laboratory scale pellet mill and pellets were dried in a forced-fan oven at $65-75^{\circ} \mathrm{C}$ and cooled at ambient temperature. Diets were manufactured by mixing all dry ingredients in a V-mixer followed by addition of addition of menhaden oil and deionized water to the mixture. The base diet and diets containing high levels of either zinc sulfate $\left(\mathrm{ZnSO}_{4} .7 \mathrm{H} 2 \mathrm{O}\right.$ reagent grade) or Mintrex ${ }^{\mathrm{TM}}$ zinc ( $24 \mathrm{ppm}$ in the base diet and $363 \mathrm{ppm}$ and $104 \mathrm{ppm}$ in the zinc sulfate and Mintrex ${ }^{\mathrm{TM}}$ zinc diets respectively) were mixed at various ratios to produce diets containing intermediate levels of either source of zinc.

The basal diet and diets containing the high level of either source of zinc were analyzed for their zinc and phytic acid concentrations. Diets were then pelleted through a $3 \mathrm{~mm}$ die and then dried in a forced air oven overnight until dry and then crumbled and sieved to the required size. All diets were stored in a $-10^{\circ} \mathrm{C}$ freezer until required. Two series of diets were formulated, one containing zinc from zinc sulfate ranging from $55-363$ ppm $(55,80,116,168,243$, and 363 ppm respectively) and the other containing zinc from Mintrex ${ }^{\mathrm{TM}}$ zinc ranging from 39-104 ppm (39, 52, 65, 78 and 104 ppm respectively) (Table 3). All experimental diets also contained approximately $1.38 \%$ phytic acid which is similar to concentrations observed in commercial aquaculture diets.

\subsection{Feeding trial}

Thirteen diets, including the base diet and a reference diet were fed to shrimp during a growth trial that was conducted at the Mariculture Laboratory at Texas A\&M University System, Port Aransas, Texas, USA. Juvenile shrimp (mean initial weight 0.40 g) were obtained from a hatchery in Texas and assigned randomly to $26 \mathrm{~L}$ tanks (8 replicates per treatment) with a $20 \mathrm{~cm}$ 
Table 1. Composition of base diet used to evaluate efficacy of dietary zinc sources in shrimp. Values are in \% on an "as fed" basis.

\begin{tabular}{ll}
\hline & \\
Ingredient & $\%$ of diet \\
\hline Casein & 13.30 \\
Gelatin & 13.00 \\
Wheat Starch & 29.67 \\
Soy Protein isolate & 7.00 \\
Squid Muscle Meal & 6.00 \\
Dicalcium Phosphate & 6.00 \\
Dry Lecithin, 95\% & 4.00 \\
Cellulose & 3.20 \\
Menhaden Fish Oil & 2.60 \\
Diatomaceous Earth & 2.50 \\
Potassium Chloride & 2.50 \\
Calcium Carbonate & 2.20 \\
Alginate (Manucol F) & 1.60 \\
Magnesium Oxide & 1.60 \\
Chromic Oxide & 1.00 \\
Sodium Hexametaphosphate & 1.00 \\
Phytic Acid & 1.00 \\
Soybean Oil & 0.60 \\
Vitamin Premix & 0.46 \\
Cholesterol & 0.20 \\
L-methionine & 0.10 \\
Vitamin C & 0.04 \\
Mintrex ${ }^{\text {TM }}$ copper (methionine hydroxy analog chelated) & 0.02 \\
Manganese Sulfate Monohydrate & 0.01 \\
Sodium Selenite & 0.00005 \\
\hline
\end{tabular}

water depth. Each tank was stocked with 6 shrimp that were fed 15 times daily with an automatic feeder to excess to attain a final FCR of approximately 2.0. Molts, shrimp waste and uneaten feed were removed daily. Shrimp were fed the zinc-deficient basal diet for 7 days prior to the trial to reduce tissue stores of zinc. Prior to this depletion period shrimp were fed a commercial diet while they were being acclimated to the experimental system. The study was carried out in two re-circulating systems that were supplied with filtered seawater of ambient salinity that was pumped in from the adjoining bay resulting in clean water experimental conditions with zero contribution from natural productivity.

The water temperature during the study was approximately $30^{\circ} \mathrm{C}$. Water temperature, dissolved oxygen, salinity, $\mathrm{pH}$ and 
Table 2. Analyzed nutrient values for base diet. All values ("as fed") are as \% of diet except for trace minerals which are in ppm.

\begin{tabular}{ll}
\hline Nutrient & $\%$ \\
& \\
\hline Crude Protein & 35.21 \\
Crude Fat & 8.31 \\
Crude Fiber & 3.97 \\
Ash & 17.12 \\
Phytic Acid & 1.38 \\
& \\
Trace Minerals & \\
Copper & 54 \\
Iron & 148 \\
Manganese & 40 \\
Zinc & 24 \\
\hline
\end{tabular}

ammonia concentrations were measured on a regular basis. The experimental systems were monitored on a daily basis for dissolved oxygen (DO), salinity and temperature using a YSI 85 Meter (Yellow Springs, Ohio, USA). Ammonia (TAN), nitrite, nitrate and $\mathrm{pH}$ were measured on a weekly basis using standard procedures.

The growth trial was conducted for 6 weeks, and at the end of the trial shrimp were weighed to calculate weight gain. Immediately afterwards 3 shrimp from each tank were pooled together with shrimp from other tanks from within each treatment and split into 3 groups per treatment. Five shrimp from each treatment group were dissected and their hepatopancreases pooled together for zinc analysis. Three shrimp from each treatment group were pooled together for whole body zinc analysis. These tissues were dried, ashed, digested with concentrated nitric acid and analyzed for zinc concentrations using ICP-AES analysis (Perkin Elmer Optima 2100DV equipped with a GEMCONE Cyclonic Spray Nebulizer; Perkin Elmer, Waltham, MA, USA). Experimental diets were similarly treated and their trace mineral concentrations determined. Proximate analysis of diets was carried out using standard methods (AOAC, 2006). Phytic acid in experimental diets was measured using ion exchange chromatography.

\subsection{Data Analysis}

Statistical analysis of data was carried out using SAS version 9.2 (Cary, North Carolina). One-way analysis of variance (ANOVA) was used to evaluate the effect of zinc source on response variables. Data were also analyzed using ANOVA with system and row as blocking factors. Where significant differences were detected $(\mathrm{p}<0.05)$ a least square means (LSMeans) test was applied to separate differences between treatments. Percentage data were arc sine transformed prior to statistical analysis. Each tank was considered as an experimental unit.

\section{Results}

\subsection{Water quality}

Water temperature during the trial was maintained at $29.5 \pm$ $0.3^{\circ} \mathrm{C}$, salinity at 35 parts per thousand and DO at $5.8 \pm$ $0.3 \mathrm{mg} / \mathrm{L}$. Total ammonia nitrogen was $0.16 \pm 0.05 \mathrm{mg} / \mathrm{L}$, nitrite nitrogen at $0.09 \pm 0.07 \mathrm{mg} / \mathrm{L}$ and nitrate nitrogen at $1.16 \pm 0.59$. Water $\mathrm{pH}$ was measured at $8.03 \pm 0.08$. Water quality conditions during the trial were maintained at levels optimal for this species.

\subsection{Performance}

The initial weight was $0.40 \pm 0.003 \mathrm{~g}$ with no significant differences observed between treatment groups. Percent survival for all treatments was high (94-98\%) with no significant differences in survival between the treatment groups (Table 4). Shrimp attained final weights of 9.55-10.59 $\mathrm{g}$ and shrimp fed diets supplemented with high levels of zinc sulfate (Z243 and Z363) exhibited significantly higher final weights than the group fed the base diet. In contrast, shrimp fed much smaller levels of supplemental dietary zinc (M65 and M78) from the chelated source showed significantly higher final weights than shrimp fed the basal diet (Table 4).

Growth rates ranged from $1.60 \mathrm{~g} / \mathrm{wk}$ to $1.78 \mathrm{~g} / \mathrm{wk}$ (Table 4). Shrimp from treatment groups Z243 and Z363 that were fed diets supplemented with zinc sulfate exhibited significantly higher growth rates than shrimp fed the base diet. Shrimp fed considerably lower levels of chelated zinc (M65 and M78) also showed significantly higher growth rates than shrimp fed the base diet.

Biomass of shrimp per $\mathrm{m}^{2}$ ranged from $546.8 \mathrm{~g} / \mathrm{m}^{2}-$ $621.6 \mathrm{~g} / \mathrm{m}^{2}$ (Table 4). Shrimp from the treatment group Z243 fed a diet supplemented with zinc sulfate showed significantly higher biomass than the control group fed the base diet. Similarly, shrimp fed diets supplemented with chelated zinc (M65 and M78), but at lower levels than that in groups fed zinc sulfate supplemented diets, also exhibited significantly higher biomass than the group fed the base diet.

Final weights and other performance parameters (Table 4) indicate that 3-4 times as much zinc from zinc sulfate was required compared to zinc from the chelated source to promote a performance response of similar magnitude. 
Table 3. Experimental treatments used to evaluate the efficacy of different sources of zinc in the Pacific white shrimp Litopenaeus vannamei

\begin{tabular}{|c|c|c|c|c|c|}
\hline Zinc Source & Diet & $\begin{array}{c}\text { Supplemental } \\
\text { Zinc, } \\
\text { mg/kg }\end{array}$ & $\begin{array}{l}\text { Total Dietary } \\
\text { Zinc } \\
\text { Concentration, } \\
\mathrm{mg} / \mathrm{kg}\end{array}$ & $\begin{array}{l}\text { Analyzed } \\
\text { Dietary Zinc } \\
\text { Concentration, } \\
\text { mg/kg* }\end{array}$ & $\begin{array}{l}\text { Phytic } \\
\text { Acid, } \\
\text { \%* }\end{array}$ \\
\hline & Base & $\begin{array}{l}0(24 \mathrm{mg} / \mathrm{kg} \text { in } \\
\text { Base) }\end{array}$ & 24 & 27 & 1.38 \\
\hline Inorganic Zinc & Z55 & 31 & 55 & $60 * *$ & \\
\hline Zinc Sulfate & $\mathrm{Z} 80$ & 56 & 80 & $85 * *$ & \\
\hline \multirow[t]{4}{*}{ (ZnSO4.7H2O) } & Z116 & 92 & 116 & $125^{* *}$ & \\
\hline & Z168 & 144 & 168 & $180 * *$ & \\
\hline & Z243 & 219 & 243 & $261 * *$ & \\
\hline & Z363 & 339 & 363 & 392 & 1.37 \\
\hline Chelated Zinc & M39 & 15 & 39 & $46^{* *}$ & \\
\hline Mintrex ${ }^{\mathrm{TM}}$ Zinc & M52 & 28 & 52 & $63 * *$ & \\
\hline $\begin{array}{l}\text { (chelated with } \\
\text { methionine }\end{array}$ & M65 & 41 & 65 & $80 * *$ & \\
\hline \multirow[t]{2}{*}{ hydroxy analog) } & M78 & 54 & 78 & $97 * *$ & \\
\hline & M104 & 80 & 104 & 131 & 1.37 \\
\hline
\end{tabular}

\footnotetext{
*The base diet and diets containing high levels of either zinc source were analyzed for zinc and phytic acid concentrations
}

${ }^{* *}$ Calculated dietary zinc values for intermediate supplemental levels of either zinc source

\subsection{Whole body and hepatopancreas zinc concentrations}

Increasing dietary zinc concentrations did not exert a consistent effect on tissue zinc concentrations (Table 5).

\section{Discussion}

Results from the study indicate that chelated zinc was more available than inorganic zinc to shrimp in the presence of phytic acid, a known trace mineral antagonist. Data suggest that shrimp required 3-4 times more inorganic zinc than chelated zinc to promote a comparable final weight, growth rate and biomass (Table 4). Performance in shrimp fed 243 and $363 \mathrm{mg} / \mathrm{kg}$ inorganic zinc were similar to shrimp fed 65 and $78 \mathrm{mg} / \mathrm{kg}$ of zinc from the chelated source, suggesting a higher requirement for zinc from an inorganic source in practical diets. This study demonstrated differences in availability of zinc between different dietary sources and these are the first results to show better performance due to organic or chelated zinc in shrimp. There are, however, numerous studies in fish showing improved availability of organic trace minerals and their subsequent effects on performance and health (Hardy and Shearer, 1985; Paripatananont and Lovell, 1995a;b; Apines et al., 2003; ApinesAmar et al., 2004a;b; Buentello et al., 2009; Laining et al., 2010; Shao et al., 2010).

Survival rates of $93 \%$ and greater were observed for the various treatments at the end of the study (Table 4). This suggests that both zinc sources were safe at the levels tested for the conditions of this experiment. In a study with the Pacific white shrimp Litopenaeus vannamei that were fed zinc-supplemented diets with or without phytate, survival ranged from 75-93\% and 73$90 \%$ for shrimp fed diets with and without phytate, respectively. No apparent reduction in survival was noted with increase in dietary zinc supplementation up to $200 \mathrm{mg}$ zinc/kg of diet (Davis et al., 1993). In black tiger shrimp Penaeus monodon that were fed diets supplemented with zinc $(0-120 \mathrm{mg} / \mathrm{kg}$ zinc), no differ- 
Table 4. Survival (\%), final weight (g/shrimp), growth rate (g/wk), and biomass in g/m2 in shrimp fed the base diet (no supplemental zinc) or different levels of supplemental zinc from either zinc sulfate $(Z)$ or chelated zinc $(M)$. All values are means \pm SEM for eight observations. The initial weight was $0.40 \pm 0.003 \mathrm{~g}$ with no significant differences in initial weight between treatments. Superscripts with the same letters are not significantly different.

\begin{tabular}{|c|c|c|c|c|c|}
\hline Diet & $\begin{array}{l}\text { Dietary } \\
\text { Zinc, ppm }\end{array}$ & $\begin{array}{c}\text { Survival } \\
\%\end{array}$ & $\begin{array}{c}\text { Final Weight, } \\
\text { g }\end{array}$ & $\begin{array}{c}\text { Growth Rate, } \\
\text { g/week }\end{array}$ & $\begin{array}{c}\text { Biomass, } \\
\mathrm{g} / \mathrm{m}^{2}\end{array}$ \\
\hline Base & 24 & 95.83 & $9.55 \mathrm{a}$ & $1.60 \mathrm{a}$ & $546.8 \mathrm{a}$ \\
\hline Z55 & 55 & 95.83 & $10.07 \mathrm{abc}$ & $1.69 \mathrm{abc}$ & $578.6 \mathrm{ab}$ \\
\hline Z80 & 80 & 95.83 & $9.73 \mathrm{ab}$ & $1.64 \mathrm{ab}$ & $560.6 \mathrm{ab}$ \\
\hline Z116 & 116 & 97.92 & 9.94 abc & $1.67 \mathrm{abc}$ & $585.1 \mathrm{ab}$ \\
\hline Z168 & 168 & 97.92 & $10.00 \mathrm{abc}$ & $1.68 \mathrm{abc}$ & $587.0 \mathrm{ab}$ \\
\hline Z243 & 243 & 97.92 & $10.59 \mathrm{c}$ & $1.78 \mathrm{c}$ & $621.6 \mathrm{~b}$ \\
\hline Z363 & 363 & 93.75 & $10.36 \mathrm{bc}$ & $1.74 \mathrm{bc}$ & $582.9 \mathrm{ab}$ \\
\hline M39 & 39 & 95.83 & $10.17 \mathrm{abc}$ & $1.71 \mathrm{abc}$ & $583.4 \mathrm{ab}$ \\
\hline M52 & 52 & 95.83 & $9.87 \mathrm{abc}$ & $1.66 \mathrm{abc}$ & $568.1 \mathrm{ab}$ \\
\hline M65 & 65 & 97.92 & 10.43 bc & 1.76 bc & $610.8 \mathrm{~b}$ \\
\hline M78 & 78 & 97.92 & $10.36 \mathrm{bc}$ & $1.74 \mathrm{bc}$ & $607.3 \mathrm{~b}$ \\
\hline M104 & 104 & 97.92 & $9.97 \mathrm{abc}$ & $1.67 \mathrm{abc}$ & $585.5 \mathrm{ab}$ \\
\hline SEM & & 0.80 & 0.08 & 0.014 & 6.28 \\
\hline
\end{tabular}

ences in survival were attributable to increases in dietary zinc. However, overall survival of shrimp ranged from $62-72 \%$ and these rates were generally lower than that seen in other shrimp studies (Shiau and Jiang, 2006).

Shrimp exhibited final weights of 9.55-10.59 $\mathrm{g}$ at the end of the $6 \mathrm{wk}$ growth trial (Table 4). The final weights of shrimp fed the base diet was significantly lower than that observed in some groups fed diets supplemented with zinc sulfate (Z243 and Z363) and chelated zinc (M65 and M78). Growth rates showed a similar pattern and shrimp from some treatment groups fed diets supplemented either with zinc sulfate (Z243 and Z363) or chelated zinc (M65 and M78) displayed significantly higher growth rates than those observed in shrimp fed the base diet (Table 4). Overall, these results indicated the need for a higher degree of zinc supplementation from an inorganic source than a chelated source to promote responses of a similar magnitude. A decreasing trend in performance was apparent at higher levels of supplementation of both zinc sources. In general shrimp from groups Z363 and M104 exhibited lower performance compared to shrimp from groups Z243 and M65 and M78 respectively, reflecting the expected quadratic response and lowered growth at higher levels of zinc supplementation.

Pacific white shrimp L. vannamei fed a purified diet contain- ing zinc-methionine exhibited significantly higher growth compared to shrimp fed either a zinc-deficient control diet or diets containing zinc sulfate, zinc-glycine or zinc-lysine (Lin et al., 2013). At the end of 12 wks shrimp (initial weight $0.72 \mathrm{~g}$ ) fed the zinc-methionine diet exhibited weight gain of $1394 \%$ while those in the other treatment groups ranged from 625-1092\%. The diets used in this study were purified and devoid of any mineral antagonists and the mechanism by which one dietary source was more available is unclear. In an earlier study with $L$. vannamei, neither final weight nor weight gain responded significantly to diets supplemented with zinc either with or without phytate (Davis et al., 1993). In shrimp fed diets without phytate, maximum weight gain was observed in shrimp fed the diet supplemented with $15 \mathrm{mg} / \mathrm{kg}$ zinc. Shrimp fed diets without phytate $(0,15,30 \& 60 \mathrm{mg} / \mathrm{kg}$ supplemental zinc) showed 1671$2523 \%$ weight gain while those fed diets with phytate $(0,60$ \& $200 \mathrm{mg} / \mathrm{kg}$ supplemental zinc) showed 1952-2272\% weight gain. The presence of phytate did not depress growth significantly but depressed hepatopancreas zinc levels and required $200 \mathrm{mg} / \mathrm{kg}$ supplemental zinc to restore levels to those seen in shrimp fed diets without phytate (Davis et al., 1993). Similarly, in an earlier trial with the same species, deletion of zinc from the mineral premix from diets fed to shrimp did not af- 
Table 5. Whole body and hepatopancreas zinc concentrations in shrimp fed diets containing either zinc sulfate $(\mathrm{Z})$ or chelated zinc $(\mathrm{M})$ or an unsupplemented base diet. All values are means.

\begin{tabular}{lccc}
\hline Diet & Dietary Zinc Level, ppm & Whole Body Zinc*, ppm & Hepatopancreas Zinc**, ppm \\
& & & \\
\hline Base & 24 & 64.05 & 97.55 \\
Z55 & 55 & 69.98 & 129.00 \\
Z80 & 80 & 71.15 & 99.80 \\
Z116 & 116 & 71.08 & 99.15 \\
Z168 & 168 & 67.18 & 155.00 \\
Z243 & 243 & 68.93 & 90.70 \\
Z363 & 363 & 67.58 & 157.50 \\
M39 & 39 & 69.98 & 117.00 \\
M52 & 52 & 66.57 & 116.70 \\
M65 & 65 & 67.02 & 117.50 \\
M78 & 78 & 64.85 & 98.50 \\
M104 & 104 & 70.48 & 117.60 \\
SEM & & 0.97 & 7.09 \\
\hline
\end{tabular}

* whole body samples were taken from each tank and pooled into 3 samples per treatment

** hepatopancreas samples were pooled into 2 samples per treatment

fect growth significantly but depressed tissue zinc concentrations (Davis et al. 1992). In P. monodon fed diets supplemented with zinc $(0-120 \mathrm{mg} / \mathrm{kg})$, shrimp fed diets supplemented with $\leqslant 35 \mathrm{mg} / \mathrm{kg}$ zinc displayed significantly greater weight gains than shrimp fed diets supplemented with $\leqslant 17.5 \mathrm{mg} / \mathrm{kg}$ of zinc (Shiau and Jiang, 2006). The relatively large initial weight of $0.44 \mathrm{~g}$ and high mortality in that study may have contributed to the lower weight gains observed which ranged from 176-244\%.

Tissue zinc concentrations were not responsive to changes in dietary zinc and no increase in either whole body or hepatopancreas zinc was observed with dietary zinc supplementation (Table 5). In an earlier study with L. vannamei, hepatopancreas zinc content was significantly affected by dietary zinc and phytate. Hepatopancreas zinc concentrations were low in shrimp fed the unsupplemened basal diet and reached a plateau at $15 \mathrm{mg} / \mathrm{kg}$. In shrimp fed diets containing phytic acid, supplementation of $200 \mathrm{mg} / \mathrm{kg}$ was required to attain hepatopancreas zinc concentrations that resembled those measured in shrimp fed phytatefree diets (Davis et al., 1993). Hepatopancreas zinc concentrations ranged from approximately $100-150 \mathrm{mg} / \mathrm{kg}$ in shrimp fed diets that did not contain phytic acid and ranged from approximately $50-130 \mathrm{mg} / \mathrm{kg}$ in shrimp fed diets containing phytic acid (Davis et al., 1993). These concentrations are similar to those measured in the present study (Table 5). In P. monodon, both whole body and hepatopancreas zinc concentrations were affected by dietary zinc supplementation. Hepatopancreas zinc concentrations increased from $0.58 \mathrm{mg} / \mathrm{kg}$ to $21.83 \mathrm{mg} / \mathrm{kg}$ when dietary zinc supplemental levels were increased from $0-120 \mathrm{mg} / \mathrm{kg}$. Whole body levels increased from $2-43 \mathrm{mg} / \mathrm{kg}$ with increasing dietary levels of zinc (Shiau and Jiang, 2006). In the Chinese mitten crab E. sinensis hepatopancreas, zinc concentrations increased from $31-132.7 \mathrm{mg} / \mathrm{kg}$ when dietary zinc levels were raised from $5-85 \mathrm{mg} / \mathrm{kg}$ (Li et al., 2010). In general, tissue zinc levels from different crustacean species were in general agreement (Depledge, 1989; Davis et al., 1992; 1993; Shiau and Jiang, 2006; Li et al., 2010). In the present study, tissue zinc concentrations were not responsive to changes in dietary zinc and it is probable that tissue zinc concentrations were maintained within a certain range. With the much higher dietary supplementation of zinc from zinc sulfate as compared to the chelated source required for the greatest performance with no changes in tissue zinc, a much greater amount of zinc would be discharged into the environment using zinc sulfate versus the chelated source in shrimp feed.

Growth results from the present study suggest that chelated zinc is more available presumably because inorganic zinc is more prone to binding by phytic acid. This results in a higher requirement for inorganic zinc to produce a comparable level of growth. Phytic acid has a strong affinity for zinc and other divalent minerals which results in their being unavailable to 
aquatic and terrestrial animals (Cheryan, 1980; Davis et al., 1993; Davis and Gatlin, 1996; Richards et al., 2010). Phytic acid has been observed to depress growth and also lower the availability of macro minerals and trace minerals in fish and shrimp (Spinelli et al., 1983; Richardson et al., 1985; Civera and Guillaume, 1989; Paripatananont and Lovell, 1995a; Usmani and Jaffri, 2002; Portz and Liebert, 2003; Helland et al., 2006; Laining et al., 2010). In the Pacific white shrimp L. vannamei, addition of phytic acid to diets did not significantly depress growth but it affected hepatopancreas zinc concentrations (Davis et al., 1993). Supplementation of excess zinc to the diet overcame the presence of phytic acid in the diet and restored hepatopancreas zinc levels to those seen in shrimp fed diets without phytic acid (Davis et al., 1993). In a trial that examined the suitability of sodium phytate and disodium phosphate as dietary phosphorus sources, no differences in growth were observed when phytate was fed to the kuruma prawn Penaeus japonicus, however the presence of phytate depressed growth in L. vannamei. Diets in the present study contained approximately $1.4 \%$ phytic acid (Table 2 ) and this is in agreement with concentrations measured in fish and shrimp feeds from different parts of the world (Novus International Inc; unpublished results).

Results from this study suggest that chelated minerals have a lower affinity for binding with phytic acid and consequently are more available to shrimp than inorganic mineral sources. There is no well established mechanism to explain this phenomenon but we hypothesize that zinc and other divalent trace elements form a very stable structure with the ligand 2-hydroxy4-methylthio-butanoic acid (HMTBa) that makes the minerals less susceptible to binding with and interference from antagonistic factors. These molecules are therefore able to reach transporters in the epithelial layer of the gut where they are transported into the enterocytes and circulation. The chelated zinc molecule is then cleaved at the gut wall with the mineral ions being transported and the HMTBa diffusing passively into the epithelial layer. The HMTBa is converted into L-methionine via a series of enzymatic steps and is utilizable by the animal (Dibner and Knight, 1984; Dibner et al, 1987; Forster and Dominy, 2006; Yi et al., 2007; Richards et al., 2010). This enables the chelated zinc source to be more available despite the presence of antagonistic factors and as a result less supplemental zinc is required to satisfy the requirement of the animal and promote growth. Higher zinc availability also has implications for the health of shrimp and that of the environment. There is concern over discharge of trace minerals into the environment from aquaculture farms and higher zinc bioavailability can ensure lower emissions into the environment. Furthermore waterborne zinc can exert an influence on the health of both cultured and wild populations of aquatic animals.

In conclusion, performance results suggest that a chelated zinc source was more available than zinc from an inorganic source to shrimp fed diets containing phytic acid. Results indicate that 3-4 times the quantity of inorganic zinc was required to promote comparable levels of growth to that observed in shrimp fed a chelated source of zinc. The study showed that zinc chelated with HMTBa was a safe, effective and highly available source of dietary zinc for the Pacific white shrimp L. vannamei.

\section{Acknowledgments}

The study was supported by Novus International, Inc. and by Texas A\&M AgriLife Research, Texas A\&M University System.

\section{References}

Ahsanullah, M., Negilski, D.S., and Mobley, M.C. 1981. Toxicity of Zinc, Cadmium and copper to the shrimp Callianassa australiensis. Marine Biology 64, 311-316.

Andreini, C., Banci, L., Bertini, I., and Rosato, A. 2006. Counting the zinc-proteins encoded in the human genome. Journal of Proteomics Research 5, 196-201.

AOAC. 2006. Official Methods of Analysis, 18th ed. AOAC International, Gaithersburg.

Apines, M. J. S., Satoh, S., Kiron, V., Watanabe, T., and Aoki, T. 2003. Availability of supplemental amino acid-chelated trace elements in diets containing tricalcium phosphate and phytate to rainbow trout, Onocrhynchus mykiss. Aquaculture 225, 431-444.

Apines-Amar, M. J. S., Satoh, S., Kiron, T., and Watanabe, T. 2004a. Effects of supplemental amino acid-chelated trace elements on the immune response of rainbow trout subjected to bacterial challenge. Journal of Aquatic Animal Health 16, 53-57.

Apines-Amar, M. J. S., Satoh, S., Caipang, C.M.A., Kiron, V., Watanabe, T. and Aoki, T. 2004b. Amino acid chelates: a better source of $\mathrm{Zn}, \mathrm{Mn}$ and $\mathrm{Cu}$ for rainbow trout Oncorhynchus mykiss. Aquaculture 240, 345-358.

Azevedo, A.O.D., Holanda, J.S., and Scudelari, A.C. 2009. Dynamics of heavy metals in the shrimp farm environment. Journal of Coastal Research 56, 1174-1178.

Blanchard, R. K., Moore, J.B., Green, C.L., and Cousins, R.J. 2001. Modulation of intestinal gene expression by dietary zinc status: effectiveness of cDNA arrays for expression profiling of a single nutrient deficiency. Proceedings of the National Academy of Science USA 98, 13507-13513.

Buentello, J.A., Goff, J.B., and Gatlin, D.M. III. Dietary zinc requirement of hybrid striped bass, Morone chrysops x Morone saxatilis, and bioavailability of two chemically different zinc compounds. Journal of the World Aquaculture Society 40, 687-694.

Cheryan, M. 1980. Phytic acid interactions in food systems. CRC Critical Reviews in Food Science and Nutrition 13, 297-335.

Cheung, K. C., and Wong, M.H. 2006. Risk assessment of heavy metal contamination in shrimp farming in Mai Po Marine Reserve, Hong Kong. Environmental Geochemistry and Health 28, 27-36.

Civera, R., and Guillaume, J. 1989. Effect of sodium phytate on growth and tissue mineralization of Penaeus japonicus and Penaeus vannamei juveniles. Aquaculture 77, 145-156.

Coleman, J. E. 1992. Zinc proteins: enzymes, storage proteins, transcription factors, and replication proteins. Annual Review of Biochemistry 61, 897-946.

Cousins, R. J. 1996. Minerals, in L.J. Filer and E. E. Ziegler (eds), Present Knowledge in Nutrition, 7th edition, International Life Sciences Institute Nutrition Foundation: Washington, 293-306. 
Cousins, R. J., Blanchard, R.K., Moore, J.B., Cui, C., Green, C.L., Liuzzi, J.P., Cao, J., and Bobo, J.A. 2003. Regulation of zinc metabolism and genomic outcomes. Journal of Nutrition 133, 1521S-1526S.

Davis, D. A., Lawrence, A.L., and Gatlin, D.M. III. 1992. Mineral requirements of Penaeus vannamei: A preliminary examination of the dietary essentiality for thirteen minerals. Journal of the World Aquaculture Society 23, 8-14.

Davis, D. A., Lawrence, A.L., and Gatlin, D.M. III. 1993. Evaluation of the dietary zinc requirement of Penaeus vannamei and effects of phytic acid on zinc and phosphorus bioavailability. Journal of the World Aquaculture Society 24, 40-47.

Davis, D. A.,and Gatlin, D.M. III. 1996. Dietary mineral requirements of fish and marine crustaceans. Reviews in Fisheries Science 4, 7599.

Depledge, M. H. 1989. Re-evaulation of the metabolic requirements for copper and zinc in decapods crustaceans. Marine Environmental Research 27, 115-126.

Dibner, J. J. and Knight, C.D. 1984. Conversion of 2-hydroxy-4(methylthio) butanoic acid to L-methionine in the chick: a stereospecific pathway. Journal of Nutrition 114, 1716-1723.

Dibner, J. J., Knight, C.D., Swick, R.A., and Ivey, F.J. 1987. Absorption of 2-hydroxy-4-(methythio) butanoic acid from the hindgut of the broiler chick. Poultry Science 67, 1314-1321.

Forster, I.P., and Dominy, W.G. 2006. Efficacy of three methionine sources in diets for Pacific white shrimp Litopenaeus vannamei. Journal of the World Aquaculture Society 37, 474-480.

Hardy, R.W., and Shearer, K.D. 1985. Effects of dietary calcium phosphate and zinc supplementation on whole body zinc concentrations of rainbow trout (Salmo gairdneri). Canadian Journal of Fisheries and Aquatic Sciences 42, 181-184.

Helland, S.V., Denstadli, V., Witten, P.E., Hjelde, K., Storebakken, T., Skrede, A., Asgard, T., and Baeverfjord, G. 2006. Hyper dense vertebrae and mineral content in Atlantic salmon (Salmo salar L.) fed diets with graded levels of phytic acid. Aquaculture 261, 603-614.

Ho, E.C., Courtemanche, C., and Ames, B.N. 2003. Zinc deficiency induces oxidative DNA damage and increases p53 expression in human lung fibroblasts. Journal of Nutrition 133, 2543-2548.

Laining, A., Traifalgar, R.F., Thu, M., Komilus, C.F., Kader, M.A., Koshio, S., Ishikawa, M., and Yokoyama, S. 2010. Influence of dietary phytic acid on growth, feed intake, and nutrient utilization in juvenile Japanese flounder, Paralichthys olivaceus. Journal of the World Aquaculture Society 41, 746-755.

Lall, S. P. 2002. The Minerals, in J. E. Halver and R. W. Hardy, eds., Fish Nutrition, Academic Press, New York, pp. 260-301.

Li, M.H., and Robinson, E.H. 1997. Microbial phytase can replace inorganic phosphorus supplements in channel catfish Ictalurus punctatus diets. Journal of the World Aquaculture Society 28, 402-406.

Li, W-W., Gong, Y-N., Jin, X-K., He, L., Jiang, H., Ren, F., and Wang, Q. The effect of dietary zinc supplementation on the growth, hepatopancreas fatty acid composition and gene expression in the Chinese mitten crab, Eriocheir sinensis (H. Milne-Edwards) (Decapoda: Grapsidae). Aquaculture Research 41, e828-e837.

Lin, S., Lin, X., Yang, Y., Li, F., and Luo, L. 2013. Comparison of chelated zinc and zinc sulfate as zinc sources for growth and immune response of shrimp (Litopeneaeus vannamei). Aquaculture 406-407, 79-84.

Mendez, L., Racotta, I.S., Acosta, B., and Rodriguez-Jamarillo, C.
2001. Mineral concentration in tissues during ovarian development of the white shrimp Penaeus vannamei (Decapoda: Penaediae). Marine Biology 138, 687-692.

Munsiri, P., Boyd, C.E., Teichert-Coddington, D., and Hajek, B.F. 1996. Texture and chemical composition of soils from shrimp ponds near Choluteca, Honduras. Aquaculture International 4, 157-168.

Naylor, R., Hardy, R., Bureau, D., Chiu, A., Elliott, M., Farrell, A., Forster, I., Gatlin, D., Goldberg, R., Hua, K., and Nichols, P. 2009. Feeding aquaculture in an era of finite resources. Proceedings of the National Academy of Sciences 106(36), 15103-15110.

Paripatananont, T., and Lovell, R.T. 1995a. Chelated zinc reduces the dietary zinc requirement of channel catfish, Ictalurus punctatus. Aquaculture 133, 73-82.

Paripatananont, T., and Lovell, R.T. 1995b. Responses of channel catfish fed organic and inorganic sources of zinc to Edwardsiella ictaluri challenge. Journal of Aquatic Animal Health 7, 147-154.

Paripatananont, T., and Lovell, R.T. 1997. Comparative net absorption of chelated and inorganic trace minerals in channel catfish Ictalurus punctatus diets. Journal of the World Aquaculture Society 28, 62-67.

Portz, L., and Liebert, F. 2003. Growth, nutrient utilization and parameters of mineral metabolism in Nile tilapia, Oreochromis niloticus (Linaeus 1758) fed plant-based diets with graded levels of microbial phytase. Journal of Animal Physiology and Animal Nutrition 88, 311-320.

Richards, J.D., Zhao, J., Harrell, R.J., Atwell, C.A., and Dibner, J.J. 2010. Trace mineral nutrition in poultry and swine. Asian-Aust. Journal of Animal Science 23, 1527-1534.

Richardson, N.L., Higgs, D.A., Beames, R.M., and McBride, J.R. 1985. Influence of dietary calcium, phosphorus, zinc and sodium phytate level on cataract incidence, growth and histopathology in juvenile Chinook salmon (Oncorhynchus tshawytscha). Journal of Nutrition 115, 553-567.

Sarker, S.A., Satoh, S., and Kiron, V. 2005. Supplementation of citric acid and amino-acid chelated trace elements to develop environmentfriendly feed for red sea bream Pagrus major. Aquaculture 248, 3-11.

Satoh, S., Tabata, K., Izume, K., Takeuchi, T., and Watanabe, T. 1987. Effect of dietary tricalcium phosphate on availability of zinc to rainbow trout. Nippon Suisan Gakkaishi 53, 199-1205.

Satoh, S., Apines, M.J., Tsukioka, T., Kiron, V., Watanabe, T., and Fujita, S. 2001. Bioavailability of amino acid-chelated and glassembedded manganese to rainbow trout Oncorhynchus mykiss fingerlings. Aquaculture Research 32, 18-25.

Shankar, A.H., and Prasad, A.S. 1998. Zinc and immune function: the biological basis of altered resistance to infection. American Journal of Clinical Nutrition 68(Suppl), 447S-463S.

Shao, X-P., Liu, W-B., Xu, W-N., Lu, K-L., Xia, W., and Jiang, Y-Y. 2010. Effects of dietary copper sources and levels on performance, copper status, plasma antioxidant activities and relative copper bioavailability in Carassius auratus gibelio. Aquaculture 308, 60-65.

Shiau, S-Y., Jiang, L-C. 2006. Dietary zinc requirements of grass shrimp Penaeus monodon and effects on immune responses. Aquaculture 254, 476-482.

Shiau, S-Y., Bai, S.C. 2009. Micronutrients in shrimp diets, in C.L. Browdy and D.E. Jory, eds.. The Rising Tide, Proceedings of the Special Session on Sustainable Shrimp Farming, World Aquaculture 2009, The World Aquaculture Society: Baton Rouge.

Spinelli, J., Houle, C.R., and Wekell, J.C. 1983. The effect of phytates 
on growth of rainbow trout (Salmo gairdneri) fed purified diets containing varying quantities of calcium and magnesium. Aquaculture $3071-83$.

Starcher, B.C., Hill, C.H., and Madaras, J.G. 1980. Effect of zinc deficiency on bone collagenase and collagen turnover. Journal of Nutrition 110, 2095-2102.

Tacon, A.G.J., and Metian, M. 2008. Global overview on the use of industrially compounded aquafeeds: Trends and future prospects. Aquaculture 285, 146-158.

Umamaheshwari, G., Srinivasan, M., and Ramanathan,T. 2011. Heavy metal concentrations from shrimp culture ponds at Point Calimere area. Current Research Journal of Biological Science 3, 73-77.

Underwood, E. J. and Suttle, N.F. 1999. The mineral nutrition of livestock. 3rd edition. CABI Publishing, New York.

Usmani, N., and Jaffri, A.K. 2002. Influence of dietary phytic acid on the growth, conversion efficiency, and carcass composition of mrigal, Cirrhinus mrigala (Hamilton) fry. Journal of the World Aquaculture Society. 33, 199-204.

Watanabe, T., Satoh, s., and Takeuchi, T. 1988. Availability of minerals in fish meal to fish. Asian Fisheries Society 1, 175-195.

Watanabe, T., Kiron, V., and Satoh, S. 1997. Trace minerals in fish nutrition. Aquaculture 151, 185-207.

Wu, J-P., and Chen, H-C. 2005. Effects of cadmium and zinc on the growth, food consumption, and the nutritional conditions of the white shrimp Litopenaeus vannamei (Boone). Bulletin of Environmental Contamination and Toxicology 74, 234-241.

Wu, J-P., Chen, H-C., and Huang, D-J. 2008. Histopathological and biochemical evidence of hepatopancreatic toxicity caused by cadmium and zinc in the white shrimp Litopenaeus vannamei. Chemosphere 73, 1019-1026.

Wu, X-Y., and Yang, Y-F. 2011. Heavy metal (Pb, Co, Cd, Cr, Cu, Fe, $\mathrm{Mn}$ and $\mathrm{Zn}$ ) concentrations in harvest size white shrimp Litopenaeus vannamei tissues from aquaculture and wild source. Journal of Food Composition and Analysis 24, 62-65.

Yi, G.F., Atwell, C.A., Hume, J.A., Dibner, J.J., Knight, C.D., and Richards, J.D. 2007. Determining the methionine activity of Mintrex organic trace minerals in broiler chicks by using radiolabel tracing or growth assay. Poultry Science 86, 877-887. 